\title{
Women's Quality of Life during the Grief Process after Perinatal Death
}

\author{
Tjaša Šapla Troha', Maša Černelič Bizjak² \\ ' Community Health Center Nova Gorica, Rejčeva 4, 5000 Nova Gorica, Slovenia \\ 2 University of Primorska, Faculty of Health Sciences, Polje 42, 6310 Izola, Slovenia \\ tjasa.troha90@gmail.com; masa.cernelic@fvz.upr.si
}

\begin{abstract}
Background: Around one fifth of pregnancies worldwide ends in miscarriage, ectopic pregnancy or stillbirth. Women often do not show their feelings after these events; they suppress them or do not talk about their loss. Unresolved grief can affect many aspects of women physical and mental health in all stages of life. Methods: The study included 108 women who experienced perinatal loss. All of them completed the Munich Grief Scale questionnaire and a questionnaire on demographic data. Results: Statistically significant differences in the experience of grief were associated with gestational age of the child $(p<0.01)$, the age of the mother $(\mathrm{p}<0.05)$ and the time that has elapsed since the child's death $(\mathrm{p}<0.01)$. In the clinical setting women judged dealing of health workers, and reported more understanding and compassionate treatment at home. The research was the basis for developing protocols with instructions for handling a situation of stillbirth, focusing on mental well-being of the mother. Discussion and conclusions: The qualification of health professionals is very important. They have the first contact with the mother and at the same time the influence to prevent the pathological processes of bereavement. Careful planning of health care and by using the protocol, nurse can gain an insight into the process of bereavement, and has a tool that focuses on procedures and activities. Keywords: grief, stillbirth, perinatal death, quality of life
\end{abstract}

The loss of a child is one of the hardest events, or namely one of the hardest and most painful experiences. People often associate grief with a wound that will slowly heal over time and eventually it will be completely healed, but the death of a child is more similar to the loss of a limb or its functioning; namely nothing can heal such a wound completely, in the case of a loss it can only come to the gradual acceptance and adjustment of the irreplace- 
able and painful loss. The society underestimates the experience in the case of the death of a newborn or in the case of a miscarriage. It is wrongly perceived that grieving is irrelevant in such cases and for that reason parents usually suppress their feelings and do not talk about their loss or ask for help. Perinatal loss therefore defies the modern expectations of a healthy outcome of pregnancy and it was proven to be as important as any other loss of a loved person (Cartwright and Read, 2005).

Grieving is a proces where we consciously say goodbye and transform the experience of a loss and integrate it in our life in a manner that we take with us what is important and essential and eventually try to move on. However, this is only possible if we manage to cope with the pain that is present, and we manage to process it in the process of grieving (Simonič, 2006).

There are many factors that determine how the grieving person will cope with the loss of a loved one: individual (gender, age, attachment, home environment), situational (cause of death, manner of receiving the news of the loss) and socio-cultural (accepted form of grief, burial ceremony, stereotypes, taboo subjects) (Ozbič, 2015); but most certainly strong emotions will always be present.

\section{Women and Expressing the Feelings in the Grief Process}

In the grieving process that usually lasts up to 24 months (Velikonja, 1999), the reactions of women are in most cases very intensive and long-lasting (Wing et al., 2001; Ozbič, 2015). In the stage of shock, experiencing depersonalization is more common for the mothers than the fathers. Right after the death of the child, intensive distress, depression and grief was observed in mothers; and all these states could still be observed long after the loss. Besides, intrusive thoughts, preoccupation, longing and the sense of being more vulnerable and anxious are also very frequent (Wing et al., 2001). Anger is intensive at the beginning of a grieving process and starts to slowly fade away over the period of two years (Ozbič, 2015). The feeling of guilt is especially present with mothers, when the cause of death is unknown. It can be inward - (they blame themselves) or outward-oriented (they blame the partner, doctors, God or fate). Searching for causes of death can be realistic (regarding medical conditions that were not in accordance with the imposed regime) or unrealistic (eating habits, recreation, sexual intercourse, arguing, thoughts or feelings about the pregnancy).

When the intensity of sadness and grief is so strong that an individual cannot accept the loss and the grief turns into depression and despair, this is called pathological grief. However, the clinical diagnosis does not know the term ,pathological grief', and therefore the ones that are treated by psychiatrist are diagnosed with depressive episode (Peljhan, 2016). The mentioned states of women reduce their quality of life as well as the lives of close family members that are also dealing with the loss in their own way. 
The quality of life here refers to the physical and mental well-being. It is based on five factors: functional state of an individual, presence of physical symptoms, emotional and social condition including social relationships and the impact of medical treatment. More and more studies research the link between the quality of life and health and also give opinions and standpoints from the patients' point of view (Kopčavar Guček in Franić, 2008).

Women's quality of life in the grief process after perinatal death is very individually oriented and can be affected by many different factors, among which are also the ones we have already mentioned. It is extremely important that grieving women are given the chance to respectfully and decently grieve; the process should start already in the maternity hospital and continue in their home environment. The key role have the health workers.

\section{Methods}

Sample

108 women participated in the survey and the average age in the time of the loss was 29.2 ( $\mathrm{SD}=5.18$ years). Participants of the survey were in average 24 weeks pregnant ( $\mathrm{SD}=9.90$ weeks). $34 \%$ of the participants, which represented the majority of women participating in the survey, had university degree, i.e. they completed the second cycle of the Bologna process. In the time of the loss of the child, $52 \%$ of women were married and $48 \%$ had a non-marital partner.

\section{Research Tools}

The initial questionnaire took demographic data, medical history, i.e. how many times were the women pregnant before and possible miscarriages or induced abortions. The questionnaire also included questions about how they received the news about their child's death, the course of stillbirth, the period after the labor and needs of the grieving mothers or both parents and what they would require afterwards from the health professional in that time. Added were also open-ended questions about their experiences of the treatment and handling in the maternity hospital from the time they were accepted in the hospital until their release and their home environment, the treatment of the home care nurse, about expressing their feelings after the loss and their search of the purpose afterwards, impacts of the loss on the relationship with the partner and their other living children and the completed grieving process.

\section{Munich Grief Scale}

Munich Questionnaire consists of 22 questions where participants answered with the Likert five point scale $(1$ - never, 2 - rarely, 3 - sometimes, 4 - often, 5 - always) and also described how they felt in that moment. The questions are combined into 5 subscales: grief (6 questions), fear of the loss (5 questions), guilt ( 5 questions), anger (3 questions) and search of the purpose (3 questions). 
The whole questionnaire consisted of: open-ended questions (15 questions), partially openended questions (1 question) and closed-ended questions (31 questions) and the Munich Grief Scale consisting of 22 closed-ended questions.

\section{Processing and Analysis of Data}

The survey was conducted via web portal $1 \mathrm{KA}$, that was available from the $8^{\text {th }}$ of January 2016 until the $8^{\text {th }}$ of March 2016. The participants agreed to participate in the survey and were explained the purpose and the objectives of the research prior to answering the questions. Data was analyzed with Microsoft Excel and SPSS ver. 20.0. The level of statistical significance was set at 0.05 .

\section{Results}

We were interested, whether the time of a miscarriage or stillbirth has any impact on the level of grief due to the loss of the child. The participants were divided into two groups: women that lost their child before the $22^{\text {nd }}$ week of pregnancy and women that lost their child in the $22^{\text {nd }}$ week or later.

\section{Table 1: Difference among women and their experiencing of grief regarding gestational age of child.}

\begin{tabular}{|c|c|c|c|c|c|c|}
\hline \multirow{2}{*}{$\begin{array}{l}\text { Gestational age of the dead } \\
\text { infant (in weeks) }\end{array}$} & \multirow{2}{*}{$N$} & \multirow{2}{*}{$M$} & \multirow{2}{*}{$S D$} & \multicolumn{3}{|c|}{$t$-test } \\
\hline & & & & $t$ & $d f$ & $p$ \\
\hline Less than $22(<22)$ & 65 & 3.70 & 0.54 & \multirow{2}{*}{2.484} & \multirow{2}{*}{106} & \multirow[t]{2}{*}{0.015} \\
\hline More or equal to $22(\geq 22)$ & 43 & 3.40 & 0.70 & & & \\
\hline
\end{tabular}

We found out that regarding the gestational age (less and equal or more than 22 weeks) there are statistically important differences among women and their experiencing of grief (Table 1).

We also wanted to know if experiencing grief might also depend on how much time has passed since the loss. Participants were further divided into two groups: women that lost their child relatively recently (i.e. less than 24 months ago) and women that experienced the loss more than 24 months ago.

Table 2: Comparisson considering time passed since the loss of the child.

\begin{tabular}{|c|c|c|c|c|c|c|}
\hline \multirow{2}{*}{$\begin{array}{c}\text { Time passed from the loss of } \\
\text { the child (in months) }\end{array}$} & \multirow{2}{*}{$N$} & \multirow{2}{*}{$M$} & \multirow{2}{*}{$S D$} & \multicolumn{3}{|c|}{ t-test } \\
\hline & & & & $t$ & $d f$ & $p$ \\
\hline Less than $24(<24)$ & 44 & 3.80 & 0.54 & \multirow[b]{2}{*}{-3.919} & \multirow{2}{*}{106} & \multirow{2}{*}{0.002} \\
\hline More or equal to $24(\geq 24)$ & 64 & 3.43 & 0.64 & & & \\
\hline
\end{tabular}

Results (Table 2) showed that how much time had passed from the critical event is a very important factor and has an impact on experiencing grief. 
Further on, we wanted to find out if the age of the mother at the time of the loss also has an impact on experiencing grief. Participants were divided into two groups: on women that were under 30 years old at the time of the loss and on those that were 30 years old or older.

Table 3: Comparisson considering the chronological age of mothers in the time of child loss.

\begin{tabular}{|c|c|c|c|c|c|c|}
\hline \multirow{2}{*}{ Chronological age (in years) } & \multirow{2}{*}{$N$} & \multirow{2}{*}{$M$} & \multirow{2}{*}{$S D$} & \multicolumn{3}{|c|}{$t$-test } \\
\hline & & & & $t$ & $d f$ & $p$ \\
\hline Less than $30(<30)$ & 60 & 3.46 & 0.63 & \multirow{2}{*}{2.297} & \multirow{2}{*}{106} & \multirow{2}{*}{0.024} \\
\hline More or equal to $30(\geq 30)$ & 48 & 3.73 & 0.59 & & & \\
\hline
\end{tabular}

We found out that there are statistically important differences considering the chronological age of mothers in the time of the child loss (Table 3).

Further on, we found out that there are no significant differences in experiencing grief, other painful feelings, memories or the need to talk about their loss, to cry and miss the child etc. in regard to seeing the child or not seeing it after the miscarriage/labor.

Whether the medical workers were understanding and sympathetic to the mothers during the time they were in the hospital, $58 \%$ of the mothers said yes and $42 \%$ said no. Out of 108 participants, $68 \%$ felt that in their home environment the health professionals (personal doctors, at the gynecologist 3 weeks after the miscarriage or 6 weeks after the labor and by home care nurses) were understanding and sympathetic towards them, while $32 \%$ of the participants said they did not receive adequate treatment by health professionals.

One of the questions of the questionnaire was regarding the loss of the child and the consequential impact it had on the relationship with their partner, which also strongly affects the quality of life during the grieving process. As much as $63 \%$ of the participants agreed that their relationship with the partner improved, $16 \%$ claimed it stayed the same and $21 \%$ of women said their relationship worsened.

\section{Discussion}

Grieving is the process of slowly letting go of the emotional attachment towards the child. Still, the woman that lost her child is experiencing strong feelings and confusion. Such emotions are present no matter how early the pregnancy terminated, even if it only lasted a few weeks. Some women do not experience grief right after a miscarriage; however, that does not mean there is something wrong with them or that they are uncaring because every individual reacts differently and the grief and disappointment can also appear at a later time (Zečević et al., 2003).

We found out that there are significant differences in experiencing grief due to various factors, namely after the loss of the child, it also depends on how 
much time had passed from a miscarriage or stillbirth. Women that lost their child in the $22^{\text {nd }}$ week of pregnancy are showing stronger emotions of grief and other painful feelings, memories, a need to talk about their child, to cry and miss it etc.

The age of the mothers at the time of the loss also proved to be an important factor because it showed to be an important indicator of experiencing grief with the participants. Namely the grieving process was more intensive with mothers that had perinatal loss at the age 30 or older than mothers that lost their child before reaching 30 years of age. The first group showed more intensive feelings of grief and other painful emotions, memories, a need to talk about their child, to cry and miss it etc.

From this we can conclude that the age of the mothers also has an impact on the intensity of grief, or how deep it is and therefore the grieving process is also longer.

The time that had passed from the loss of the child and to the time the survey was carried out is also one of the important indicators that showed in which grieving stage the participant was or if she already completed the grieving process. Participants that experienced the loss of their child 24 months ago are still expected to show certain grieving patterns in comparison to women, who experienced the loss over 24 months ago. When the intensity of grief is so strong that an individual cannot accept the loss, which can eventually lead to depression and despair, it is called pathological grief (Peljhan, 2016). Results of the conducted survey showed that in average women got pregnant again 15 months after the loss.

The results also showed a significant difference in experiencing grief among the participants regarding the time that had passed from the loss of the child. Women that experienced the loss of the child 24 months prior to conducting the research (44 out of 108 participants) showed more intensive emotions of grief and other painful feelings, memories, the need to talk about their child, to cry and to miss it etc.

After the loss it is very important that the parents decide how long they should wait to get pregnant again. In any case, there is no rule when is the right time, but it is important that the woman lets herself grieve and deals with her feelings of the loss. A little over one third of the women participating in the survey were already pregnant again before they answered the questionnaire. Only one participant got pregnant as soon as one month after the loss of her child, which is rather fast. Regarding the theory of the grieving process, an individual after a critical loss barely moves from the stage of shock and realizes the reality of the loss in one month, as the acute stage of the grieving lasts from 2 to 6 weeks (Velikonja, 1999). Among the women participating in the survey the longest time that passed from the loss of the child to another pregnancy was 5 years. 
It is an interesting fact that Gravensteen et al. (2013) came to completely opposite conclusions regarding holding or seeing the child after stillbirth or miscarriage. Namely they found out that seeing the baby afterwards had a positive effect on the grieving process and therefore they encouraged health workers to prepare the parents to see their child and spend the time with it to say goodbye.

However, it is concerning that only $58 \%$ of the participants were treated with understanding and sympathy by health workers. From the answers of our participants and other surveys (Baznik, 2005) we can conclude that parents criticized and had a negative experience with health workers after the loss of their child. According to other research, the grieving parents also said they did not get enough information regarding the tests made after the death of their child, the cause of death and the consequences the loss can have on the mother and her chances of getting pregnant again. Gravensteen et al. (2013) further on discovered that the majority of women were given support (85.6\%) during the labor and were respectfully treated (94.4\%) with the stillborn baby by the health workers.

It is of great importance that the help is offered to the parents' right after the loss of their child because it can reduce the risk of a negative outcome. The help can be offered by the doctors, nurses and other interdisciplinary members of the team, including psychologists and social workers (Wing et al., 2001).

More sympathy and understanding was given by health workers in the home environments of our participants, as was claimed by $68 \%$ of the participants. When asked, what they would require from the health workers in their home environments, women's answers varied. Majority claimed that they would need more pieces of advice on how to move on and where to look for help further on. This is the role of community nurse that has to document all the observations of a mother after stillbirth. In the case of a problematic outcome that the home care nurse cannot resolve by her own, a selected doctor, gynecologist or other suitable institution has to be informed (Kraševec, 2002).

\section{Conclusion}

In the health care process of the obstetric and gynecological care only emphatic healthcare workers should be employed due to special sympathetic treatment women should be given as they are under the influence of many hormones after giving birth. And when we also deal with perinatal death, the health workers should, besides being compassionate, also have enough knowledge and willingness to educate themselves further. Additional training is essential for health workers because, firstly they also have to deal with the loss themselves. And secondly, it is their help that is of extreme importance in such critical period for the parents as it can effect and make a difference between a healthy grieving process and an unhealthy one. 
It is of great importance that the woman and her needs would truly be put first in the postnatal care. One of the participants of the survey wrote that she "would wish that they would think about the particularities" and gave us a great starting point for further research. Namely, the parents should be able to talk to the midwife or a nurse after receiving the sad news, who would explain the course of the labor, important information and encourage the parents to see and hold the baby and even name it, inform them of the grieving process, the nature and process of the bureaucracy and also offer them the time they need to think about their own needs in connection to their dead child, no matter how hard it is for them. When the parents would be given all the information right after they had received the sad news about the death of their child or already when they are accepted into the hospital for the arranged induced labor, they would cope better after seeing their child and also with their expectations and the reality of the loss. The positive effects of such a talk would later be observed during their grieving process and would also affect their quality of life in the process. We should also be aware of the fact that the grieving process of the parents cannot be alleviated and parents also do not want that from us. Our caring and sensibility that come before realization can help us to understand the pain of others, to listen to them and offer them our help (Globevnik Velikonja, 2000) that is in such times very much needed.

Later in the grieving process we should also encourage grieving women and other family members to search for additional psychological and therapeutical help in order to cope more efficiently with their feelings. It would also be very wise to integrate women in complementary methods of coping with their grief and other emotions. One of such efficient methods is the EFT (Emotional Freedom Technique), a technique to achieve emotional freedom (Craig, 2007). The EFT is a tool that helps to ease negative emotions and offers many ways to solve emotional problems (Craig, 2007; Fone, 2012).

\section{References}

BAZNIK, S., 2005 Podpora staršem ob izgubi kritično bolnih otrok v enotah intenzivne zdravstvene nege in terapije. Obzornik zdravstvene nege, letn. 39, št. 1, str. 47-53.

CARTWRIGHT, P., READ, S., 2005. Working with practititioners to develop training in peri-natal loss and bereavement: Evaluating three workshops. Nurse Education in Practice, letn. 5, št. 1, str. 266.

CRAIG, G., 2007. EFT raziskave [spletni vir]. [Datum dostopa 16. 5. 2017]. Dostopno na http://www.eftuniverse.com/

FONE, H., 2014. (5. NATIS) EFT - Tehnika doseganja čustvene svobode za telebane. Ljubljana: Pasadena.

GRAVENSTEEN, I. K., HELGAdótTIR, L. B., JACOBSEN, E. M., RÅDESTAD, I., SANDSET, P. M., EKEBERG, O. 2013. Women's experiences in relation to stillbirth and risk factors for long-term post-traumat- 
ic stress symptoms: a retrospective study. BMJ Open. [Datum dostopa: 13.05.2017]. Dostopno na http://bmjopen.bmj.com/content/3/10/eoo3323

KRAŠEVEC, B., 2002. Zdravstvena nega otročnice. Postojna: Zbornica zdravstvene nege Slovenije - Zveza društev medicinskih sester in zdravstvenih tehnikov Slovenije.

KOPČAVAR GUČEK, N., FRANIĆ, D. 2008. Kakovost življenja, svetovanje in hormonsko nadomestno zdravljenje. Zdravniški vestnik, letn. 77, št. 3, str. 73-78.

KOROŠEC, M., NOVAK, U., ZEVNIK, H. 2007. Ob izgubi, ki jo doživlja mladostnik. Ljubljana: Salve.

OZBIČ, P., 2015. Medsebojna podpora partnerjev v procesu žalovanja po otrokovi smrti. Psihološka obzorja, letn. 24, str. 44-56.

PELJHAN, M., 2016. Žalovanje, zadovoljstvo $z$ življenjem in partnerski odnos ob zgodnji izgubi otroka: magistrsko delo. Ljubljana: Univerza v Ljubljani, Teološka fakulteta, magistrski študijski program zakonska in družinska terapija.

SIMONIČ, B., 2006. Prva resnica je rojstvo, zadnja je smrt. Anthropos, letn. 38, št. 1-2(201-202), str. 173-181.

VELIKONJA, V., 1999. Psihološka pomoč staršem ob otrokovi smrti. Psihološka obzorja, letn. 8, št. 1, str. 93-103.

WING, D.G., CLANCE, P.L., BURGE-CALlAWAY, K., ARMISTEAD, L., 2001. Understanding gender differences in bereavment following the death of an infant: implications for treatment (Prevedla: Sara Topolovec). Psychotherapy, letn. 38, št. 1, str. 60-73.

ZEČEVIĆ B, UREK P, KOKOL S, CEHNER M., 2003. Prazna zibka, strto srce: staršem, ki so izgubili otroka med nosečnostjo ali kmalu po porodu. Krško: Društvo Solzice, str. 17, 65. 